\title{
GAGASAN CERITA PANJI SEBAGAI ASPEK KETELADANAN
}

Henri Nurcahyo

\begin{abstract}
The Panji story is a popular cultural heritage during the Majapabit period, spreading to various regions and countries of Southeast Asia. Panji's story is not just a romantic story of Panji Asmarabangun with Dewi Sekartaji but has many interesting aspects that can be studied from various sides. There are many fairy tales that tell the story of Panji, as well as the performing arts of tradition, art, the art of chanting, and even the Panji Story enshrined in reliefs of dozens of temples in East Java and hundreds of manuscripts of Panji scattered in various countries. From the various stories of Panji is contained noble values that can be a role model in the life of society and state. In the story of Panji there is a load of courage, heroism, unyielding spirit, creativity in running tactics, caring for others, love animals and flora, not vengeance, do not apply cruelly, love to study, devoted to mother, love and master various art and so on. The Panji is an ideal figure so much is personified by many Kings throughout history. The story of the Panji becomes intertwined between fairy tales and facts. The Panji story becomes a myth that eventually becomes a reference in life. In fact, the example of the Panji Story is not only reflected in its traits as a person but the moral of the story contained in $i t$, as well as the inspiration that can be picked as a raw material for the creation of artwork and also the creative economy.
\end{abstract}

Keywords: Panji story, cultural heritage, exemplary, heroism, myth

\section{PENDAHULUAN}

Dalam pemahaman secara mainstream, Cerita Panji dapat dikisah-singkatkan sebagai sastra lisan yang berkisar mengenai percintaan Raden Panji Asmarabangun (Inu Kertapati atau Panji Kudawanengpati), putera mahkota kerajaan Jenggala, dengan Dewi Sekartadji (Galuh Candrakirana), puteri kerajaan Panjalu atau Kadiri. Namun jalinan kasih sepasang sejoli ini tidak berjalan mulus, banyak romantika berupa petualangan dan penyamaran hingga Cerita Panji kemudian melahirkan banyak versi dan varian berupa dongeng dan kisah-kisah lainnya. Meski pada akhirnya mereka berhasil menjadi sepasang suami isteri yang memerintah Kerajaan Kadiri, namun berbagai persoalan seakan tak pernah henti menimpa mereka sehingga justru semakin banyak melahirkan cerita-cerita baru lagi.

Tetapi cerita yang seperti tersebut di atas hanyalah salah satu versi saja, masih banyak versi lain dalam Cerita Panji ${ }^{1}$. Bahkan, dalam pemahaman yang lebih luas, Cerita Panji tidak hanya berurusan dengan Raden Panji dan Candrakirana, atau hanya berkisar mengenai kerajaan Janggala dan Panjalu. Dan yang tidak banyak tahu, bahwa masih banyak dongeng lain yang tidak secara langsung merupakan dongeng Panji namun memiliki semangat yang sama. Cerita Sri Tanjung misalnya, dapat disebut

\footnotetext{
${ }^{1}$ Dialog interaktif budaya "Aspek Keteladanan Pada Cerita Panji” 14 Februari 2018, bersama LPIK UNIPA Surabaya
} 
sebagai cerita yang memiliki spirit Cerita Panji. Yaitu, kisah kasih yang terhalang, tentang kesetiaan seorang perempuan kepada pasangannya, dan perjuangan sang lelaki yang tak kenal takut menghadapi bahaya demi menunaikan sebuah tugas negara. Demikian pula Angling Darmo di Bojonegoro, dan juga Damar Wulan.

Arkeolog M. Dwi Cahyono berpendapat, bahwa yang dimaksud Cerita Panji adalah berbagai kisah dalam beragam ekspresi dengan tokoh sentral Panji. Disebut Cerita Panji karena memiliki pola-pola tertentu, yaitu (1) tokohnya kekesatriaan, (2) memiliki pola integrasidistegrasi-reintegrasi atau ketemu-pisah-ketemu lagi dan mengalami siklus berulang. (3) Ada kesan bermusuhan tetapi bersatu, seperti Romeo Yuliet, ada upaya penyatuan. (4) Ada balada yang segenerasi tapi bisa lintas generasi. ${ }^{2}$

Tetapi M. Dwi Cahyono juga menyebut adanya khasanah cerita lainnya yang dalam sejumlah hal memiliki indikator serupa dengan cerita Panji, meski tidak ditokoh-sentrali oleh Panji Asmorobangun dan Dewi Sekartaji serta tidak berlatarkan sejarah Jenggala-Pangjalu. Indikator yang serupa dengan cerita-cerita Panji itu antara lain : (a) pola alur penceritaan (integrasi-disintegrasi-reintegrasi), (b) melibatkan tokoh peran dari kalangan ksatria bergelar 'Panji' - sebagai tokoh peran utama, (c) bermuatan kisah asmara dramatik, yang melibatkan tokoh

\footnotetext{
2 "Khasanah Panji Minor di Penjuru Jawa Timur. Sumber Keasi bagi Seni Budaya Panji”. Makalah Revitalisasi Seni Tradisi Berbasis Budaya Panji. UPT Laboratorium Pelatihan dan Pengembangan Kesenian Dinas Kebudayaan dan Pariwisata Provinsi Jawa Timur, Oktober 2016
}

peran pria dan wanita yang saling kasih, (d) berlatar sejarah Masa Hindu-Buddha atau masa sesudahnya, (e) berwilayah geografis Jawa khususnya Jawa Timur, dan terkadang pula menjangkau wilayah luar Jawa bahkan luar Nusantara. Terhadap kisah-kisah Panji demikian, Pigeaud (1967-1970,I:29) mengatagorikan sebagai "Cerita Panji Minor (Minor Panji Romance)'.

Cerita Panji berkembang pesat bersamaan dengan tumbuhnya kerajaan Majapahit menjadi kerajaan klasik terbesar dan terakhir di nusantara. Majapahit sebagai kerajaan besar yang berkuasa di kepulauan tentunya dihormati oleh kerajaan-kerajaan Asia Tenggara. Pada masa itulah Kisah atau Cerita Panji secara berangsurangsur menyebar berbarengan dengan keharuman nama Majapahit di Asia Tenggara. Penduduk wilayah Asia Tenggara dan semenanjung tentu rela mengadopsi Kisah Panji sebagai salah satu khasanah sastra mereka. Jadi Kisah Panji sebenarnya adalah simbol kejayaan Majapahit itu sendiri, simbol pencapaian peradaban kedaton-kedaton di Jawa bagian timur dalam era Majapahit berkuasa. ${ }^{3}$

Meski "hanya" berupa kisah percintaan dua anak manusia, seorang arkeolog asal Jerman, Lydia Kieven, ketika meneliti sosok yang mengenakan topi (tekes) di relief 20 candi di Jawa Timur, menemukan ada 7 (tujuh) candi yang dipastikan terkait dengan Cerita Panji dan 5

\footnotetext{
3 Agus Aris Munandar dan Ninie Susanti. "Makna Kisah Panji”. Makalah Seminar Cerita Panji sebagai Warisan Dunia. Perpustakaan Nasional, 28-29 Oktober 2014
} 
candi lain diduga terkait Cerita Panji. ${ }^{4}$ Sementara Agus Aris Munandar dan Ninie Susanti mendeskripsikan ada 10 (sepuluh) bangunan kepurbakalaan dari era Majapahit yang mengandung relief Cerita Panji. ${ }^{5}$ Fakta yang menarik ini melahirkan pertanyaannya, apakah ada sesuatu yang luar biasa sehingga sampai sebegitu banyak bangunan kepurbakalaan yang mengabadikan Cerita Panji? Lebih-lebih, semua artefak itu ternyata dibangun pada masa Majapahit.

Ada banyak keistimewaan Cerita Panji sebagaimana sudah dikaji oleh banyak ilmuwan. Bahkan Cerita Panji yang merupakan cerita asli Indonesia yang bersumber dari kerajaan Kadiri dan Jenggala ini ternyata menyebar ke seluruh Jawa, Bali, Nusa Tenggara, menyeberang ke Sumatra, Kalimantan, bahkan hingga ke negaranegara Malaysia (semenanjung Melayu), Thailand, Kamboja, Laos dan Myanmar. Cerita Panji adalah pusaka budaya yang sangat berharga, pernah menjadi kebanggaan zaman Kerajaan Majapahit, dan sudah seharusnya dikenali dan menjadi kebanggaan kembali oleh masyarakat Jawa Timur pada masa kini.

Cerita Panji adalah sebuah pusaka budaya (Cultural Heritage). Pusaka (heritage) yang terdiri dari pusaka berwujud atau bendawi (tangible heritage) dan tak berwujud (intangible heritage). Yang termasuk Pusaka Bendawi sebagaimana yang sudah ditetapkan oleh Unesco yaitu: Candi Borobudur, Taman Nasional Komodo, Candi
Prambanan, Taman Nasional Ujung Kulon, Situs Manusia Purba Sangiran, Taman Nasional Lorentz, Hutan Hujan Tropis Sumatera, dan Subak di Bali. Sedangkan pusaka tidak berwujud (intangible heritage) dari Indonesia yang juga diakui oleh Unesco adalah Wayang, Keris, Batik, Angklung, Tari Saman, dan 3 genre Tarian Bali yang terdiri dari tari sakral (wali), tari semi-sakral (bebali), dan 3 tari hiburan (balih balihan).Cerita Panji, dalam hal naskahnya, aalah jenis pusaka budaya yang tergolong Ingatan Dunia (Memory of the World). Setelah menggandeng beberapa negara akhirnya naskah-naskah Panji berhasil mendapatkan pengakuan Unesco sebagai Memory of the World (MoW) sebagaimana yang sudah pernah didapatkan oleh Indonesia atas Arsip VOC (bersama negara India, Afrika Selatan dan Sri Lanka), I La Galigo, Babad Diponegoro, Negarakrtagama, dan Arsip Konperensi Asia Afrika Bandung 1955, oleh Indonesia (Arsip Nasional RI) bersama India, Pakistan, Srilanka dan Myanmar. Lantaran Naskah Panji memang terdapat tidak hanya di Indonesia, maka pengajuan ke Unesco juga melibatkan beberapa negara lain, yaitu Malaysia, Kamboja, Belanda dan Inggris. Sementara Thailand yang sebetulnya memiliki ratusan naskah Panji justru tidak terlibat dalam penganugrahan ini. Bersama dengan penetapan naskah Panji ini Unesco juga menetapkan arsip-arsip renovasi Candi Borobudur dan Tsunami Asia Pasifik.

\footnotetext{
${ }^{4}$ Lydia Kieven meneliti hal ini sebagai bahan kajian disertasi doktoralnya di Sydney University dengan judul: "Following the Cap-Figure in Majapabit Temple Reliefs"

${ }^{5}$ Agus, Ninie: opcit
} 


\section{DASAR TEORITIS}

\section{Kondisi Faktual Cerita Panji}

Pada masa sekarang ini, kebanyakan masyarakat umum mengenal Cerita Panji dalam bentuk dongeng, seperti Andhe-ande Lumut, Keong Mas, Panji Laras, Enthit dan banyak lagi. Bahkan mereka yang mengaku sudah akrab dengan dongeng-dongeng tersebut tidak menyadari bahwa apa yang sudah dikenalnya sejak masih anak-anak itu tergolong Cerita Panji. Selain itu Cerita Panji juga menjadi bahan baku cerita dalam seni pertunjukan tradisional seperti Wayang Topeng, Wayang Beber, Wayang Krucil, Jaranan, Kethek Ogleng, dan sebagainya. Sementara segolongan kecil lainnya mengetahui Cerita Panji pada naskah-naskah kuno yang ternyata jumlahnya mencapai ratusan dan menyebar di berbagai negara.

Pusaka budaya yang diklaim berasal dari Jawa Timur itu malah hampir tidak banyak dikenali di tanah kelahirannya sendiri. Atau setidaknya bukan menjadi sesuatu yang populer. Cerita Panji justru masih terpelihara dengan baik di Bali (yang disebut Malat) dan lebih terkenal di Semenanjung Melayu dengan sebutan Hikayat atau juga di Thailand dengan nama Kisah Inou dan Bossaba. Kondisi ini berdampak pada semakin memudarnya berbagai seni pertunjukan yang mengambil bahan baku Cerita Panji, khususnya di Jawa Timur.

Sejumlah seni (pertunjukan) tradisional yang berbahan baku Cerita Panji masih sanggup bertahan dengan adanya upacara adat berupa bersih desa, ritual bulan Suro, saat ada nadzar atau acara ritual lainnya. Dengan kata lain, keberadaan upacara adat itu dapat disebut sebagai benteng terakhir kebertahanan seni pertunjukan tradisional. Seni tradisi nampaknya lebih banyak bertahan dalam fungsi sakral. Sementara seni tradisi dalam perannya sebagai sarana hiburan atau fungsi profan nyaris tidak mendapat tempat atau malah semakin hilang sama sekali. Meski tidak semua, sudah semakin sedikit orang punya hajat atau ada perayaan tertentu yang mendatangkan seni pertunjukan tradisi, khususnya yang berbasis Cerita Panji.

Sampai dengan tahun 2004, khususnya di Jawa Timur, keberadaan Cerita Panji masih sebatas menjadi pengetahuan para akademisi yang menjadikannya sebagai objek penelitian, kajian ilmiah untuk meraih jenjang akademis yang lebih tinggi. Meskipun, bisa saja ada sejumlah akivitas terkait Cerita Panji seperti mengangkat dalam sebuah lakon pertunjukan, kajian diskusi atau semacamnya. Keberadaan Cerita Panji timbul tenggelam seiring dengan perjalanan waktu. Belum terdengar ada sebuah tekad untuk memopulerkan kembali Cerita Panji sebagaimana kejayaannya pada masa Majapahit. Cerita Panji adaah harta karun yang masih tersimpan rapi di kotaknya dalam sebuah gua.

Maka pada tanggal 12 Agustus 2004, ada sebuah pertemuan kecil di Pusat Kerjasama Budaya dan Bahasa Prancis (CCCL) Surabaya yang diprakarsai oleh Soeprapto Suryodarmo (Padepokan Lemah Putih Solo), Lydia Kieven (arkeolog dan pakar Panji dari Jerman) serta Suryo Wardoyo Prawiroatmojo (Ashoka Fellow dan pegiat lingkungan dan budaya, Trawas, Mojokerto). Menurut catatan daftar hadir, 
termasuk ketiga pemrakarsa itu tercatat ada 19 nama yang mengikuti pertemuan ini, antara lain: Sholeh Adipramono (padepokan Mangundarmo Malang), Henricus Supriyanto (budayawan, Malang), Miroto dan Djarot (Solo), Sinarto (Taman Budaya Jatim), Widodo Basuki (Majalah Jayabaya), Abdul Lathif (Kompas), Himawan Cahya (Sekolah Ciputra), Michael Tendean (Sekolah YPPI Surabaya), Diane Butler (Dharma Nature Centre, Bali), Mamik Santoso (Ubaya Trawas), dan beberapa nama lagi, termasuk dari CCCL sendiri.

Tujuan dan harapan pertemuan waktu itu antara lain: (a). Membicarakan rencana penyelenggaraan suatu program Panji yang komprehensif, menurut tataran seni budaya, sosiologi, sejarah sampai penanaman kebangsaan pada generasi muda. (b). Membicarakan kemungkinan adanya suatu "Panji Centre" yang menggalang poros seni budaya Panji: Bali - Jawa Timur - Jawa Tengah dan DIY serta jaringan di negeri berbudaya Panji, seperti Thailand, Cambodia dan Champa (Vietnam Selatan).

Dalam pertemuan tersebut lantas mengemuka beberapa pernyataan penting: Pertama, bagi generasi muda yang mulai tidak/kurang mengenali lagi budaya lokal dari leluhurnya, sebagai prioritas penting harus dicobakan menerapkan beberapa cara, antara lain: memperkenalkan kembali seni budaya lokal yang masih hidup, misalnya kunjungan ke padepokan dan sanggar budaya, mendalami budaya dan ritual pertanian serta kehidupan lainnya, seperti tumpengan, ruwatan dan sebagainya. Juga memperkenalkan musik pentatonis, perpaduan pentatonis dan diatonis. Untuk kalangan sekolah, bagaimana memperkenalkan dan menggunakan nama-nama serta istilah-istilah dalam budaya Panji, misalnya nama Taman Anggraeni untuk kebun sekolah.

Kedua, dengan mewariskan dan menerapkan budaya leluhur ini diharapkan manusia serta daerahnya diharapkan lebih "santun" karena tidak terkontaminasi tata cara yang kasar, serta teguh mempertahankan nilai jati diri.

Ketiga, perlu dikembangkan lebih lanjut akar pada budaya pertanian. Bagaimana model pertanian di Tumpang yang sudah mengembangkan pertanian "Jawa" Perlu mengembalikan budaya pertanian ini, misalnya dengan Beras Panji, Lombok jenis Panji, juga Panji sebagai simbol panen palawija, yang sebetulnya telah dikenal luas pada budaya pertanian rakyat. Karena itu perlu dikembangkan lebih lanjut konsep sosial-budaya desa, dengan membawa konsep-konsep pertanian, tata desa, tata ruang dan sebagainya.

Keempat, perlu dikembangkan suatu sistem "Taman Budaya Desa/Rural" dengan gagasan konsep holistik: kesenian, adat istiadat, kebiasaan hidup, peralatan-perlengkapan hidup yang mencerminkan sejarah perkembangan peradaban masyarakat secara luas, sebagaimana masyarakat Indonesia 80 persen pedesaan. Contoh peradaban dan budaya rural yang bertahan misalnya seperti di Jogja di lereng Merapi dan Merbabu, lereng Gunung Lawu dan masyarakat Tengger. Jika dapat diperluas lebih 
lanjut tentu akan mendapat simpati dan dukungan luas.

Kelima, pengembangan dan khususnya penamaan-peristilahan budaya Panji jangan menggunakan nama Majapahit karena untuk beberapa kalangan di luar Jawa hal ini membawa citra penjajah dan militeristik yang mengganggu dan sangat merugikan. Lebih-lebih karena rencana lanjutan budaya Panji ini sekali-sekali tidak mengekspose politik dan kekuasaan, namun mengungkapkan masalah nilai manusia yang berguna. Budaya Panji sendiri jauh lebih tua daripada Majapahit walaupun berkembang lebih luas pada zaman itu.

Keenam, perlu adanya tahapan dalam pengembangan Budaya Panji ini. Yang pertama kali dilakukan adalah eksplorasi lebih lanjut, menentukan bentuk kegiatan lebih lanjut, apakah festival, pasamuan atau kolaborasi dengan berbagai aspeknya, yaitu meliputi seni rupa, kriya, gerak dan bunyi, bentuk ukiran (disebut motif Panji Sosi) sampai kepada seni bangunan dan tata ruang wilayah.

Ketujuh, pada tahun 2005, tepat 60 tahun Indonesia merdeka adalah momen yang tepat untuk penyelenggaraan suatu acara besar skala internasional berpusat pada Budaya Panji, membahas berbagai segi lewat workshop, seminar, pelatihan, kajian ilmiah, diskusi serta pertunjukan dan demo misalnya membahas sulukan dan janturan Panji Majapahitan, ritual desa, nilai sakral topeng, ruwayan dan sebagainya.

Catatan notulensi Pertemuan Seni Panji yang ditulis oleh Suryo W. Prawiroatmojo itu akhirnya merumuskan beberapa Rencana Tindak Lanjut (RTL) yaitu:

1. Menyelenggarakan suatu "Pasamuan Budaya Panji Mancanagari” dengan berbagai kegiatan: workshop, seminar, pelatihan, pertunjukan tentang berbagai bentuk budaya Panji; seni gerak, bunyi, kriya, lukis, motif, performance art, sastra, arsitektur bangunan dan pertanian.

2. Pasamuan direncanakan diselenggarakan September 2005 di lokasi Jawa Timur dengan peserta semua wilayah yang berbudaya Panji; Siam (Thailand), Khmer Kambodia, Champa (Vietnam), Panji Melayu serta wilayah-wilayah di Jawa, Bali dan Lombok.

3. Mengembangkan sarana-sarana Balai Budaya Desa dengan Budaya Panji sebagai dasarnya, dikembangkan pada berbagai aspek seperti tersebut di atas, menjadi suatu Taman Budaya Desa.

4. Melanjutkan pengembangan nilai Budaya Panji melalui pendidikan.

5. Melanjutkan serta mengembangkan caracara pertanian sehat dan alami dari cara pertanian Budaya Panji.

Namun sayang sekali gagasan besar itu tidak (belum sempat) terlaksana, dan baru pada tahun 2007 dapat diwujudkan sebagian berupa seminar internasional di Universitas Merdeka Malang. Pada saat yang bersamaan juga dilakukan aktivitas kesenian berbasis Panji di Padepokan Mangundarmo, Tumpang, Malang dengan prakarsa M. Soleh Adipramono dan juga di Trawas oleh Suryo W. Prawiroatmojo. 
Demikianlah, sejak itu berbagai acara dengan tema Budaya Panji terus menggelinding, yaitu "Pasamuan Budaya Panji Internasional" di Pusat Pendidikan Lingkungan Hidup (PPLH) Seloliman, Trawas dan Candi Patirtan Jalatunda, Mojokerto, tahun 2008. Pada saat inilah Dewan Kesenian Jawa Timur sebagai salah satu penyelenggara mencanangkan program Konservasi Budaya Panji. Bahkan juga mencanangkan Cerita Panji sebagai ikon budaya provinsi Jawa Timur. Tetapi lantaran saat itu Cerita Panji memang belum populer maka pencanangan ikon budaya itu hilang dihembus angin.

Hajatan berikutnya dilangsungkan di kompleks Candi Penataran (2009, 2010), Diskusi Intensif di Pusat Kebudayan Prancis Surabaya, bahkan event tahunan Malang Tempo Doeloe memiih tema utama Cerita Panji. Kemudian berlanjut ke Jombang (2011), dan terus menggelinding di berbagai kota termasuk kawasan Pasar Klithik Solo, Pasuruan, Candi Sukuh Karang Anyar, Museum Paduraksa Borobudur, Malang, Mojokerto, Kediri, Yogyakarta, Bandung dan Jakarta. Bahkan, Festival Panji Internasional kemudian digelar di Thailand awal tahun 2013. Disusul Festival Topeng Internasional di Solo tahun 2014 yang sebagian besar menampilkan juga Cerita Panji.

Dari serangkaian kerja swadaya ini akhirnya sanggup menggugah kepedulian pemerintah sehingga diselenggarakan Festival Nasional Panji di Kediri (Juli 2017) hasil kolaborasi Pemkab Kediri, Pemprov Jatim dan Kemendikbud RI. Acara serupa kemudian diperluas ke tingkat Asia pada bulan Juli tahun ini dimulai di Denpasar Bali, Surabaya, Kediri, Blitar dan Malang, berlanjut ke Yogyakarta dan Jakarta.

\section{Relevansi Cerita Panji}

Cerita Panji merupakan warisan sejarah masa lalu yang adiluhung, pernah berjaya di masa lampau, khususnya era Majapahit, hingga menyebar ke berbagai daerah di nusantara dan beberapa negara Asia Tenggara. Bahwasanya fakta Cerita Panji banyak terdapat di relief candi merupakan sebuah "misteri" tersendiri. Sedemikian istimewakah Cerita Panji pada masa itu sehingga kemudian dipahatkan dalam banyak relief di candi-candi yang kesemuanya dibangun pada akhir masa Majapahit. Malah di Candi Selokelir di lereng gunung Penanggungan pernah ditemukan sebuah patung Raden Panji yang kini berada di perpustakaan seni rupa ITB Bandung. Konon, patung ini tidak sendiri, bisa jadi ada patung Dewi Sekartaji yang entah dimana keberadaannya sekarang ini.

Juga merupakan hal yang menarik dikaji, mengapa banyak seni pertunjukan yang membawakan Cerita Panji, baik sebagai cerita satu-satunya, cerita utama, ataupun menjadi salah satu referensi cerita yang dibawakan oleh seni pertunjukan tersebut. Padahal, dalam dunia seni pertunjukan biasanya dikuasai oleh ceritacerita besar dari India yaitu Mahabarata dan Ramayana. Bisa jadi bahwa Panji yang merupakan Cerita asli Indonesia memang sedang berdaya sebagai "Budaya Tanding" 
budaya dari luar, khususnya dalam konteks waktu itu adalah budaya India.

Belum lagi sekian banyak dongeng berbasis Cerita Panji yang tersebar dan masih populer di masyarakat hingga sekarang ini. Sedemikian populernya dongeng-dongeng tersebut sampai-sampai kebanyakan orang tidak menyadari bahwa yang diketahuinya sejak masa kanak-kanak sebagai dongeng pengantar tidur itu sesungguhnya adalah dongeng Panji. Misalnya saja, dongeng Ande-ande Lumut, Keong Emas, Panji Laras, Enthit, dan sebagainya. Khusus dongeng Timun Mas, ada yang salah kaprah dengan dongeng ini. Bahwa dongeng Timun Mas yang menyebut-nyebut seorang gadis lahir dari buah timun, dibesarkan perempuan desa, melawan raksasa hingga raksasa tenggelam dalam lumpur. Itu semua sebetulnya bukan dongeng Panji melainkan dongeng dari Jawa Tengah. Memang ada disebut-sebut dongeng Timun Mas sebagai dongeng Panji, namun tidak ada gadis yang lahir dari buah timun karena gadis itu sebetulnya adalah Dewi Sekartaji yang sedang menyamar. Juga tidak ada danau lumpur, meski disebut juga ada raksasa yang mengejar Timun Mas namun berhasil dikalahkan pemuda petani yang tidak lain adalah Raden Panji Inu Kertapati yang juga sedang menyamar.

Dongeng Sri Tanjung yang dikaitkan dengan asal-usul kota Banyuwangi adalah juga bagian dari Cerita Panji. Dalam dongeng itu dikisahkan perihal seorang perempuan bernama Sri Tanjung dituduh selingkuh dengan Raja oleh suaminya sendiri. Patih Sidopekso yang tidak percaya kesetiaan isterinya, lantas menusukkan senjata ke tubuh isterinya. Dengan penuh kesedihan Sri Tanjung bersumpah apabila dirinya sampai dibunuh, jika yang keluar bukan darah, melainkan air yang harum, maka itu merupakan bukti bahwa dia tak bersalah.

Akhirnya dengan garang Sidapaksa yang sudah gelap mata menikam Sri Tanjung dengan keris hingga tewas. Maka keajaiban pun terjadi, benarlah persumpahan Sri Tanjung, dari luka tikaman yang mengalir bukan darah segar melainkan air yang beraroma wangi harum semerbak. Raden Sidapaksa menyadari kekeliruannya dan menyesali perbuatannya. Sementara sukma Sri Tanjung terbang ke Swargaloka dan bertemu Dewi Durga.

Setelah mengetahui kisah ketidakadilan yang menimpa Sri Tanjung, Sri Tanjung dihidupkan kembali oleh Dewi Durga dan para dewa. Sri Tanjung pun dipersatukan kembali dengan suaminya. Para dewa memerintahkan Sidapaksa untuk menghukum kejahatan Raja Sulakrama. Ia pun membalas dendam dan berhasil membunuh Raja Sulakrama dalam suatu peperangan. Konon air yang harum mewangi itu menjadi asal mula nama tempat tersebut. Maka sampai sekarang ibu kota kerajaan Blambangan dinamakan Banyuwangiya ng bermakna "air yang wangi".

Legenda Sri Tanjung ini memiliki spirit Cerita Panji, yang oleh Pigeaud digolongkan sebagai Panji Minor. Kesamaan dengan Cerita Panji adalah mengisahkan kisah kasih yang terhalang, kesetiaan seorang perempuan kepada pasangannya dan juga perihal perjuangan sang 
lelaki yang tak kenal takut menghadapi bahaya demi menunaikan sebuah tugas negara.

Legenda ini dilukiskan antara lain dalam relief di Candi Surowono, dimana Patih Sidopeksa yang tahu Sri Tanjung tidak bersalah, dia kemudian memangku jenasah isterinya dalam posisi sangat mirip dengan Raden Panji Asmarabangun berkisah kasih dengan Candrakirana.

\section{HASIL KAJIAN DAN PEMBAHASAN}

\section{Keistimewaan Cerita Panji}

Apakah keistimewaan Cerita Panji sehingga layak dijadikan keteladanan? Cerita Panji mewakili suatu mahakarya (masterpiece) kejeniusan kreatif manusia sebab digubah oleh para pujangga Jawa kuno dengan tema dan lokasi cerita di Tanah Jawa sendiri. Cerita Panji juga tidak mendapat pengaruh asing, namun justru mempengaruhi kebudayaan masyarakat Asia Tenggara secara luas, menjelaskan peradaban masyarakat Jawa Kuno antara abad ke 14-15 dan merupakan dokumentasi sejarah kebudayaan di Asia Tenggara secara luas.

Cerita Panji merupakan cerita asli Indonesia yang bersumber dari kerajaan Kadiri dan Jenggala ini ternyata menyebar ke seluruh Jawa, Bali, Nusa Tenggara, menyeberang ke Sumatra, Kalimantan, bahkan hingga ke negaranegara Malaysia (semenanjung Melayu), Thailand, Kamboja, Laos, dan Myanmar. Asal tahu saja, Cerita Panji malah lebih memasyarakat di Thailand, dikenalkan di bangku sekolah dan buku Cerita Panji itu sendiri ditulis oleh raja Thailand sendiri, yaitu Raja Rama. Di Thailand
Cerita Panji dikenal sebagai Cerita Inao, berasal dari kata Inu Kertapati. "Sepanjang pengetahuan saya, tidak ada hasil kesusasteraan yang bersemangat Jawa yang penyebarannya di seluruh Kepulauan Nusantara menyamai penyebaran Cerita Panji." (Poerbatjaraka, 1968: 409-410) Bahkan sangat dimungkinkan sastra Panji merupakan satu-satunya karya sastra Indonesia yang hingga saat ini paling banyak dipelajari oleh berbagai bangsa di dunia. ${ }^{6}$

Senada dengan hal itu maka guru besar Universitas Malaya, Abdul Rahman Kaeh, dalam seminar internasional Budaya Panji di Malang (2010) memberi kesaksian, bahwa: Orang Jawa boleh berbangga dengan Cerita Panji. Cerita ini memang asli kepunyaan mereka. Cerita-cerita seperti Ramayana, Mahabarata, Adiparwa, Wirataparwa, Kakawin Arjuna Wiwaha, Kakawin Smaradahana, Hikayat Seri Rama, Hikayat Sang Boma, dan sebagainya, tidak dapat dikatakan asli kepunyaan mereka, kerana ceritacerita tersebut walaupun telah digubah dan disesuaikan dengan lingkungan alam Jawa, tetapi kita masih dapat mengetahui negeri asalnya, iaitu India. Sebaliknya kalau kita mau mencari negeri asal Cerita Panji ini di tempat lain tentulah tidak mugkin, kerana cerita yang bersifat demikian hanya bisa kita temui di Jawa saja. ${ }^{7}$

Manakala dirunut dari aspek sejarah, kisah ini terjadi pada masa kerajaan Kadiri, namun justru muncul dua ratus tahun sesudah itu, yaitu

\footnotetext{
${ }^{6}$ Bambang Pudjasworo, 2014: Cerita Panji sebagai Sumber Inspirasi Penciptaan Seni Pertunjukan. (Dalam Prasetya, St. Hanggar B; Prosiding Seminar Tokoh Panji Indonesia, Depdikbud dan ISI Yogyakarta.

${ }^{7}$ Kaeh, Abdul Rahman: "Cerita Panji, Sumber Kajian yang Masih Menarik", dalam Panji Pahlawan Nusantara, editor Henri Supriyanto, belum diterbitkan.
} 
pada masa kerajaan Majapahit. ${ }^{8}$ Dari sini saja sudah memancing kajian sejarah dan aspek politik yang menarik diperbincangkan. Bahkan, mempersoalkan apakah Panji ini memang merupakan fakta sejarah atau hanya dongeng belaka, sudah menjadi bahan diskusi yang seru. Dalam bab tersendiri di buku ini diulas kaitan antara Cerita Panji dan aspek sejarah ini.

Cerita Panji adalah sastra klasik tingkat dunia yang asli berasal dari Indonesia, khususnya dari Jawa Timur. Meski beragam Cerita Panji yang beredar namun semangatnya tetap sama yaitu pengembaraan dan kemenangan sang pahlawan yang hidup dalam budaya Jawa Kuna, bukan budaya yang berasal dari India. Lydia Kieven bahkan menyebut bahwa sastra Panji adalah salah satu contoh khas untuk kreativitas pada zaman Jawa Timur. Naskahnya atau versi lisan diciptakan pada zaman itu dan tidak berdasarkan ada sastra India. Cerita Panji adalah bukti kreativitas budaya Jawa Timur. ${ }^{9}$

Bahwa sesungguhnya Cerita Panji bukan hanya bercerita mengenai kisah percintaan belaka. Filosofi Cerita Panji adalah mengenai "mencari dan menemukan", seperti kisah tentang rembulan dan matahari yang digambarkan bagaikan sepasang kekasih. Bulan adalah lambang kesetiaan dan ketulusan cinta. Janji bulan untuk tetap setia pada matahari. Jadi

\footnotetext{
${ }^{8}$ Perihal kapan Cerita Panji tercipta masih menjadi perdebatan. Ada yang bilang sebelum Majapahit sudah ada. Bahkan Puteri Gayatri, isteri Raden Wijaya konon disebut-sebut sebagai pengagum berat dan mempersonifikasikan diri sebagai Dewi Candrakirana. ${ }^{9}$ Kieven, Lydia, 2014. "Simbolisme Cerita Panji dalam Relief-Relief di Candi Zaman Majapahit dan Nilainya pada Masa Kini", makalah dalam seminar di Perpusnas, Oktober 2014.
}

Panji adalah lambang siang, matahari, lelaki; dan Candrakirana adalah lambang malam, rembulan dan asas keperempuanan semesta. Berbagai varian Cerita Panji selalu mengisahkan upaya pencarian yang dilakukan dengan sungguhsungguh, penuh dengan halang rintang, termasuk harus melakukan penyamaran. Namun usaha keras itu akhirnya tidak sia-sia. Cerita Panji mengajarkan perihal kesetiaan dan usaha keras untuk menjaganya, meski di saat yang sama kesetiaan itu sendiri memiliki tafsir yang berbeda.

Cerita Panji itu lahir lantaran masyarakat pada saat itu merindukan bersatunya dua kerajaan, Jenggala dan Kadiri yang dipimpin oleh dua raja bersaudara yang sama-sama keturunan Airlangga. Pada mulanya, ketika Airlangga hendak mengundurkan diri sebagai Raja Jenggala lantaran usia lanjut, dia kebingungan lantaran memiliki dua orang putera yang dianggap sama-sama berhak menjadi Raja. Sementara puteri sulungnya, Dewi Kilisuci, tidak berminat menjadi pewaris dan memilih bertapa sebagai Bikhu. Singkat cerita, meski kerajaan kemudian sudah dibagi dua untuk kakak beradik, namun keduanya masih sering berseteru karena menganggap tidak adil. Dan hal ini berlangsung hingga keturunan ketiga. Maka lahirnya Cerita Panji adalah sebuah simbolisme agar kedua bersaudara itu berdamai dengan cara menjodohkan masing-masing putera dan puterinya. ${ }^{10}$

\footnotetext{
10 Tafsir mengenai hubungan saudara ini bisa bermacammacam. Ada yang menyebut saudara sepupu, namun ada yang mengatakan bahwa mereka merupakan keturunan
} 
Cerita Panji berkembang pesat bersamaan dengan tumbuhnya kerajaan Majapahit menjadi kerajaan klasik terbesar dan terakhir di nusantara. Majapahit sebagai kerajaan besar yang berkuasa di kepulauan tentunya dihormati oleh kerajaan-kerajaan Asia Tenggara. Pada masa itulah Kisah Panji secara berangsur-angsur menyebar berbarengan dengan keharuman nama Majapahit di Asia Tenggara. Penduduk wilayah Asia Tenggara dan semenanjung tentu rela mengadopsi Kisah Panji sebagai salah satu khasanah sastra mereka. Jadi Kisah Panji sebenarnya adalah simbol kejayaan Majapahit itu sendiri, simbol pencapaian peradaban kedatonkedaton di Jawa bagian timur dalam era Majapahit berkuasa. ${ }^{11}$

Ternyata, meski sudah terkenal ternyata tidak diketahui siapa pencipta Cerita Panji. Bandingkan dengan Negara Krtagama (Mpu Prapanca), kakawin Sutasoma (Mpu Tantular), kakawin Arjuna Wiwaha (Mpu Kanwa), Serat Dewa Ruci (Empu Siwamurti). Meskipun Kitab Pararaton dan Kidung Sudamala juga tidak diketahui penulisnya, namun Cerita Panji merupakan mahakarya susastra yang digubah secara bersama-sama oleh masyarakat Jawa Kuna, bukan oleh satu dua Mpu. Kisah Panji telah mengalami penambahan dan perluasan narasi yang berbeda-beda sesuai dengan selera pujangga penggubahnya. ${ }^{12}$ Bahkan sampai sekarang pun Cerita Panji ini masih terus

ketiga. Sebagai karya sastra, hal ini tidak penting dipersoalkan.

11 Agus Aris Munandar dan Ninie Susanti. "Makna Kisah Panji”. Makalah Seminar Cerita Panji sebagai Warisan Dunia. Perpustakaan Nasional, 28-29 Oktober 2014. 12 opcit berkembang dengan versi-versi baru yang digubah sendiri dalam pementasan Wayang Topeng di Malang dan juga beberapa novel populer.

Berbeda dengan naskah-naskah kuno tersebut di atas, popularitas Cerita Panji diceritakan dalam berbagai bentuk seni, termasuk cerita rakyat yang menandakan cerita ini juga tersebar di kalangan rakyat dan bukan hanya menjadi karya intelektual yang hanya dikonsumsi kalangan elit dan terbatas. Cerita Panji tidak hanya berhenti pada naskah namun berkembang sebagai cerita anak-anak yang juga disukai orang kebanyakan.

Dan kalau mau alasan lain untuk menguatkannya, berikut ini simpulan (theorema) yang disampaikan Agus Aris Munandar dalam makalahnya di Seminar "Panji dalam Berbagai Tradisi Nusantara" di Yogyakarta bulan Mei 2014, ${ }^{13}$ yang sekaligus ditambahkan dalam urutan keistimewaan Cerita Panji.

Kisah Panji memiliki nilai universal luar biasa, yaitu menjadi acuan kepahlawanan, penghargaan kemanusiaan, mengetengahkan etika pergaulan, dan diplomasi pergaulan. Hal itu terlihat dari sepak terjang Raden Inu atau Panji dalam kisah-kisahnya, tokoh tersebut pada dasarnya selalu menjunjung nilai-nilai peradaban dan kemanusiaan.

Kisah Panji mewakili suatu mahakarya (masterpiece) kejeniusan kreatif manusia sebab

\footnotetext{
${ }^{13}$ Munandar, Agus Aris (2014): Panji dan para Kadeyan Mengembara dalam Kebudayaan Nusantara. Dalam Prosiding Seminar Tokoh Panji Indonesia: Panji dalam Berbagai Tradisi Nusantara.
}

Jurnal Budaya Nusantara Vol. 1 No. $2 \mid 127$ 
digubah oleh para pujangga Jawa kuno dengan tema dan lokasi cerita di Tanah Jawa sendiri, tidak mendapat pengaruh asing, namun memengaruhi kebudayaan masyarakat Asia Tenggara secara luas.

Uraian Kisah Panji memberikan gambaran tentang tahapan-tahapan penting dari sejarah kehidupan manusia. Kisah Panji menjelaskan peradaban masyarakat Jawa Kuno antara abad ke 14-15 dan merupakan dokumentasi sejarah kebudayaan di Asia Tenggara secara luas.

Secara langsung atau nyata terkait dengan suatu peristiwa atau tradisi kehidupan: Kisah Panji menjelaskan perihal tradisi perjodohan yang dikenal meluas di Asia Tenggara dengan cara (a) dijodohkan (dipertunangkan), memilih sendiri, (c) pasangan merupakan hadiah sayembara. Diuraikan juga adanya tradisi pergantian kuasa raja-raja secara damai dan sejahtera sebagaimana yang didambakan dalam sejarah kebudayaan Asia Tenggara.

Satu hal yang istimewa, Cerita Panji memiliki autentisitas karya: Kisah Panji adalah otentik, tidak menjiplak atau meniru karya-karya lain, walaupun terdapat tema universal tentang percintaan, namun keasliannya tetap tampil dan hal itu diakui oleh masyarakat yang mengapresiasinya. Cerita Panji dapat dibandingkan dengan karya lain sezaman (Pararaton, Sri Tanjung, Sudamala dan Calon Arang), maka Kisah Panji memunyai kekhususan tersendiri. ${ }^{14}$

\footnotetext{
${ }^{14}$ Uraian selengkapnya dapat dibaca di buku "Memahami Budaya Panji” oleh Henri Nurcahyo, Pusat Konservasi Budaya Panji, 2016
}

Lantas, bagaimana dengan sifat dan karakter tokoh Panji itu sendiri? Dari beberapa sumber sastra, babad, maupun data arkeologis, R.M. Yunani kemudian merumuskan karakter Panji sebagai berikut: ${ }^{15}$

1. Berwajah yang tampan sebagai kesatria

2. Bersikap pendiam dan anggun.

3. Berjiwa lemah lembut, manjing ajur ajer.

4. Gemar menuntut ilmu dan gemar membaca

5. Seniman gamben (piawai) dan mumpuni berbagai cabang seni.

6. Bertabiat jujur dan lurus hati.

7. Taat kepada orangtua terutama ibu.

8. Menyayangi binatang, terutama hewan piaraan.

9. Ramah dan sopan terhadap sesamanya.

10. Setia dan menghormati para istrinya.

11. Simpatik dan menarik karena memiliki ilmu asmara (asmaragama, asmaratantra, asmaranala, dan asmaraturida).

12. Pandai menulis di kertas lontar.

13. Pahlawan perang sehingga dijuluki Kusuma Yudha.

14. Piawai menari dan bermain gamelan.

15. Piawai mendalang wayang.

Dalam dunia pewayangan, karakter Panji tersebut ternyata sama persis dengan sosok Arjuna. Itulah sebabnya komikus R. Kosasih ketika melukiskan Panji dalam komik Panji Semirang tidak sedikitpun berbeda dengan sosok Arjuna yang (antara lain) dilukiskan dalam komik Arjuna Sasrabahu. Karena itu, sosok yang

\footnotetext{
${ }^{15}$ RM. Yunani Prawiranegara: "Sang Panji Pahlawan Kebudayaan", dalam Konservasi Budaya Panji, Dewan Kesenian Jawa Timur, 2010, editor Henri Nurcahyo
} 
diukir dalam sepasang cengkir dalam tradisi mitoni masyarakat Jawa bukan hanya dapat dimaknai sebagai Dewa Kamajaya dan Dewi Ratih, bukan hanya Raden Arjuna dan Dewi Sembadra, tetapi juga Raden Panji dan Dewi Sekartaji.

Sedemikian idealnya karakter seorang Panji maka banyak perempuan ingin menjadi isterinya; Banyak orangtua yang ingin mengambilnya menjadi menantu; Banyak raja atau semua laki-laki ingin meniru sifat-sifatnya; Dan tidak jarang ada Raja yang mengklaim sebagai personifikasi Panji. Itu sebabnya ada kerancuan sejarah yang menganggap Cerita Panji sebagai sebuah fakta sejarah hanya karena ada raja bernama Panji yang beristerikan Candrakirana.

Padahal, Panji bukanlah figur nyata yang ada dalam sejarah. Panji adalah sebuah karakter protagonis. Panji adalah sosok ideal yang dapat melekat pada siapapun. Bahkan menurut I Wayan Dibia, masyarakat di Bali yang memiliki sifat jujur dan berani mendapatkan julukan Panji.

\section{PENUTUP DAN KESIMPULAN}

Lantaran sosok Panji memang identik dengan tokoh protagonis itulah maka sudah selayaknya Panji menjadi teladan dalam berkehidupan. Bagi dunia pendidikan, Cerita Panji dapat dikemas sedemikian rupa sebagai bahan ajar untuk anak didik. Para guru musti memahami lebih dulu apa itu cerita Panji, kemudian mengkreasikan dalam berbagai mata pelajaran yang diampunya.
Diperlukan langkah inventarisasi Cerita Panji yang tersebar dalam bentuk dongeng, lakon-lakon seni pertunjukan, kidung, maupun yang sudah divisualisasikan dalam relief-relief candi. Hal ini karena cerita Panji banyak tersebar di berbagai media namun belum ada yang mendokumentasikannya dalam sebuah buku tersendiri.

Sebagaimana sebuah harta karun maka Cerita Panji harus dikelola sedemikian rupa dengan berbagai kreasi tanpa harus takut akan kehabisan, sebab berbeda dengan sumberdaya alam yang akan habis kalau digali maka Cerita Panji sebagai sumberdaya budaya justru akan semakin berlimpah manakala terus menerus digali.

Keteladanan dari Cerita Panji bukan hanya yang tercermin dari sifat-sifatnya saja sebagai pribadi namun moral cerita yang terdapat di dalamnya, dan juga inspirasi yang dapat dipetik sebagai bahan baku penciptaan karya seni dan juga ekonomi kreatif.

\section{DAFTAR PUSTAKA}

Depdikbud dan ISI Yogyakarta,

2014: Prasetya, St. Hanggar B (ed); Prosiding Seminar Tokoh Panji Indonesia.

Dinas Kebudayaan dan Pariwisata Provinsi Jawa'Timur,

2016: "Revitalisasi Seni Tradisi Berbasis Budaya Panji." Tidak diterbitkan. 
Kieven, Lydia,

2014. "Menelusuri Figur Bertopi Dalam Relief Candi Zaman Majapahit. Pendangan Baru terhadap Fungsi Religius Candicandi Periode Jawa Timur Abad ke 1415. Kepustakaan Populer Gramedia.

Munandar, Agus Aris,

2014: "Catuspatha Arkeologi Majapahit". Wedatama Widya Sastra.

Nurcahyo, Henri, (ed)

2010: "Konservasi Budaya Panji”, Dewan Kesenian Jawa Timur.

Nurcahyo, Henri, 2016: "Memahami Budaya Panji”, Pusat Konservasi Budaya Panji.

Perpustakaan Nasional Republik Indonesia, 2014: "Cerita Panji Sebagai Warisan Dunia", prosiding seminar naskah kuna nusantara.

Simbolisme Cerita Panji dalam Relief-Relief di Candi Zaman Majapahit dan Nilainya pada Masa Kini”, makalah dalam seminar di Perpusnas, Oktober 2014.

Supriyanto, Henri (ed). "Panji Pahlawan Nusantara", belum diterbitkan. 